\title{
THE TRANSFORMATION OF ECOSYSTEMS OF THE ILI RIVER DELTA (KAZAKHSTAN) UNDER THE FLOW REGULATION AND CLIMATE CHANGE
}

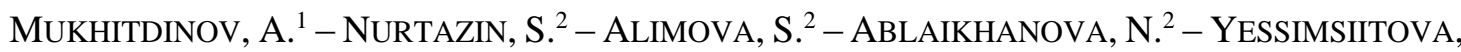 \\ $\mathrm{Z}^{2}{ }^{2}$ - SAlMURZAUly, R..$^{*}$ - MARGULAN, I. ${ }^{2}-$ MiRASBEK, Y. ${ }^{2}$ \\ ${ }^{1}$ Satbayev Kazakh National Technical University, Almaty, Kazakhstan \\ ${ }^{2}$ Al-Farabi Kazakh National University, Almaty, Kazakhstan \\ *Corresponding author \\ e-mail: zhanat_2006@mail.ru \\ (Received $9^{\text {th }}$ Dec 2018; accepted $8^{\text {th }}$ Jan 2020)
}

\begin{abstract}
This paper presents the results of a study on the main reasons for the transformation of wetland ecosystems in the Delta of the Ili River in the period of 1979-2014. The study results are shown based on the analysis of multi-temporal satellite data Landsat, dynamics of hydrological regime of the river Ili, climate conditions and features of economic activities of the local community, as well as fieldwork in the study region. Analysis of area changes of main types of hydromorphic and semi-hydromorphic ecosystems of Delta river Ili in high and medium on water discharge in the following $(1979,1993,2000$, 2010, and 2015) years. Increasing water consumption in China and in Kazakhstan part of the Ili-Balkhash basin due to the development of the agrarian and municipal sectors of economy especially in China, significantly exceed increasing flow of Ili River, caused by regional warming in the catchment part of Ili River Basin. The global warming has intensified the degradation of glaciers in mountain catchment areas of Ili River, this in the near future threatens with a decline in river flow and as a consequence lead to the deterioration of delta ecosystems and the desiccation of lake Balkhash similarly to the ecological disaster of the Aral Sea. Analysis of long-term (from 1970 to 2013) climatic data from three meteorological stations demonstrated a trend of the regional increase of average annual air temperature by $1.4{ }^{\circ} \mathrm{C}$ and decreasing of average annual precipitation by $10 \mathrm{~mm}$. These factors also contribute to the transformation process of hydromorphic ecosystems.
\end{abstract}

Keywords: Ili-Balkhash basin, Ili Delta, hydrology, ecosystem transformation, climate warming and anthropogenic pressure

\section{Introduction}

The processes of landscape degradation in river deltas in connection with regulation of runoff, in recent years has given more consideration (Hajdarov, 1968; Magasheva, 1977; Plisak, 1981; Starodubtsev et al., 1978). Similar works were carried out during the filling of Kapchagai reservoir from 1969 to1989 on the middle stream of river Ili, which provides nearly $80 \%$ of the water inflow into the largest inland water body in Kazakhstan - Lake Balkhash (Evstifeev et al., ND; Sovolova and Zhelnova, 1984; Plisak and Ogar, 1985). Ili is the most abounding in water river of South-East Kazakhstan. More than 3 million people live in the basin, and over many years a large industrial and agricultural complex was formed, which occupies an important place in the socio-economic life of the country.

The lower reaches of river Ili from Kapshagai ravine to the estuary, lies in the western part of the Balkhash flat depression. Modern Ili Delta geomorphologically enters into its composition and covers an area about $8000 \mathrm{~km}^{2}$, as well as it is currently the largest River Delta in Central Asia. The Delta is represented as mosaics of zonal- 
desert and intrazonal-floodplain-lowland hydromorphic biocenoses. This latter is distinguished by high biological productivity and cenotic biodiversity in the delta that are crucial for the conservation of some rare and endangered species and populations of animals and plants, as well as the unique wetland ecosystems (Jensen et al., 1987; Frazier et al., 2003). Ili Delta and the southern part of Lake Balkhash were declared as wetlands of international importance and included in the list of the Ramsar Convention in February 2012 (Du et al., 2014).

Since the 1970s, due to a sharp increase in water consumption and construction of reservoirs in Kazakhstan, and then in the Chinese part of the River Ili Basin, the runoff was significantly reduced in the lower reaches. This led to a sharp deterioration of water cut of floodplain and wetland areas and aridization of hydromorphic landscapes with the expansion of zonal, desert-like ecosystems (Tso and Mather, 2009). Quite a large number of articles are published on the threatening ecological situation in the IliBalkash basin, which is a reminder to the well-known catastrophe of the Aral region (Kanika et al., 2013; Congalton and Green, 1999; Neasset, 1996; Cherednichenko et al., 2010). However, volume of standard observations that were conducted previously was sharply reduced in 1990s, in particular, part of weather stations and gauging stations has been closed and field scientific studies are almost stopped (Vilesov et al., 2006). Currently, it is very little data on the current environmental state of the Basin in general and the modern Delta of the Ili River. In view of this, the aim of the study that had been done in 2008-2015, was to examine the main trends in the transformation of wetland ecosystems of the Ili River in relation to the regulation of river flow, regional climate changes, and anthropogenic impacts on the delta biocenoses.

\section{Methods}

The methods and multi-temporal remote sensing data were used in this study taking into account the large area of the Ili River Delta. Multi-temporal comparative analysis of biocenoses and classification of main studied biocenoses were based on the Landsat series: Multispectral Scanner (MMS); Thematic Mapper (TM); Plus Enhanced Thematic Mapper (ETM+) and Operational Land Imager (OLI), which are widely used in the world in the investigations of wetlands and delta ecosystems (Burlibaev et al., 2004, 2011). The time interval of used satellite images based on the changes of Ili Delta over the past 36 years due to fluctuations of average annual runoff from the relatively watershort years $(1979,1993,2015)$ to an average water year (2000) and abnormally high 2010. These satellite images are in open access (http://earthexplorer.usgs.gov) Table 1. In selecting of satellite images all standard quality criteria (minimum cloudiness, image clarity and comprehensive coverage of the study area) was taken into account, as well as date of images, which were focused on the full-flowing months: June and July. In addition to remote data a complex fieldwork was carried out in 2008-2015 and during the fieldwork data were collected on land cover, features of terrestrial and aquatic landscapes on 382 representative points from different types of biocenoses.

Data from the gauging station "The tract Kapshagay" which is located on $37 \mathrm{~km}$

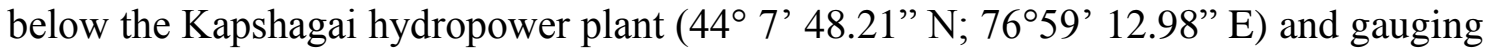
station 164 which located in $164 \mathrm{~km}$ further upstream of Kapshagai hydropower plant $\left(43^{\circ} 51^{\prime} 20.00^{\prime \prime} \mathrm{N} ; 79^{\circ} 11^{\prime} 53.38^{\prime \prime} \mathrm{E}\right)$ were used to analyze dynamics of hydrological regime of the lower reaches of the Ili River for the period of 1950 to 2013. 
Apart from runoff, the fluctuations of weather conditions also have a significant impact to the delta. An analysis of average annual fluctuations of air temperature and precipitation for the period of 1970-2012 was made based on the data of the weather stations Aul-4 and Kuigan, which located in the Delta (Fig. 1). Long-term runoff and climate data were purchased from the National Hydrometeorological Service "Kazhydromet". Influence of various forms of economic and human activities to the delta ecosystem were also taken into account.

Table 1. Information on the used satellite images

\begin{tabular}{c|c|c|c}
\hline Identification image number & Date & $\begin{array}{c}\text { Shooting scene of Landsat } \\
\text { path/row (WRS) }\end{array}$ & Name of the SC \\
\hline LM21630291979171AAA05 & 20.06 .1979 & $163 / 29$ & Landsat 2 MMS \\
LM21630281979171AAA05 & 20.06 .1979 & $163 / 28$ & Landsat 2 MMS \\
LT51510291993161ISP00 & 10.06 .1993 & $151 / 29$ & Landsat 5 TM \\
LT51510281993161ISP00 & 10.06 .1993 & $151 / 28$ & Landsat 5 TM \\
LE71510292000157SGS00 & 05.06 .2000 & $151 / 29$ & Landsat 7 ETM + \\
LE71510282000157SGS00 & 05.06 .2000 & $151 / 28$ & Landsat 7 ETM + \\
LT51510291993161ISP00 & 10.06 .2010 & $151 / 29$ & Landsat 5 TM \\
LT51510281993161ISP00 & 10.06 .2010 & $151 / 28$ & Landsat 5 TM \\
LC81510292015190LGN00 & 09.07 .2015 & $151 / 29$ & Landsat 8 OLI \\
LC81510282015190LGN00 & 09.07 .2015 & $151 / 28$ & Landsat 8 OLI \\
\hline
\end{tabular}

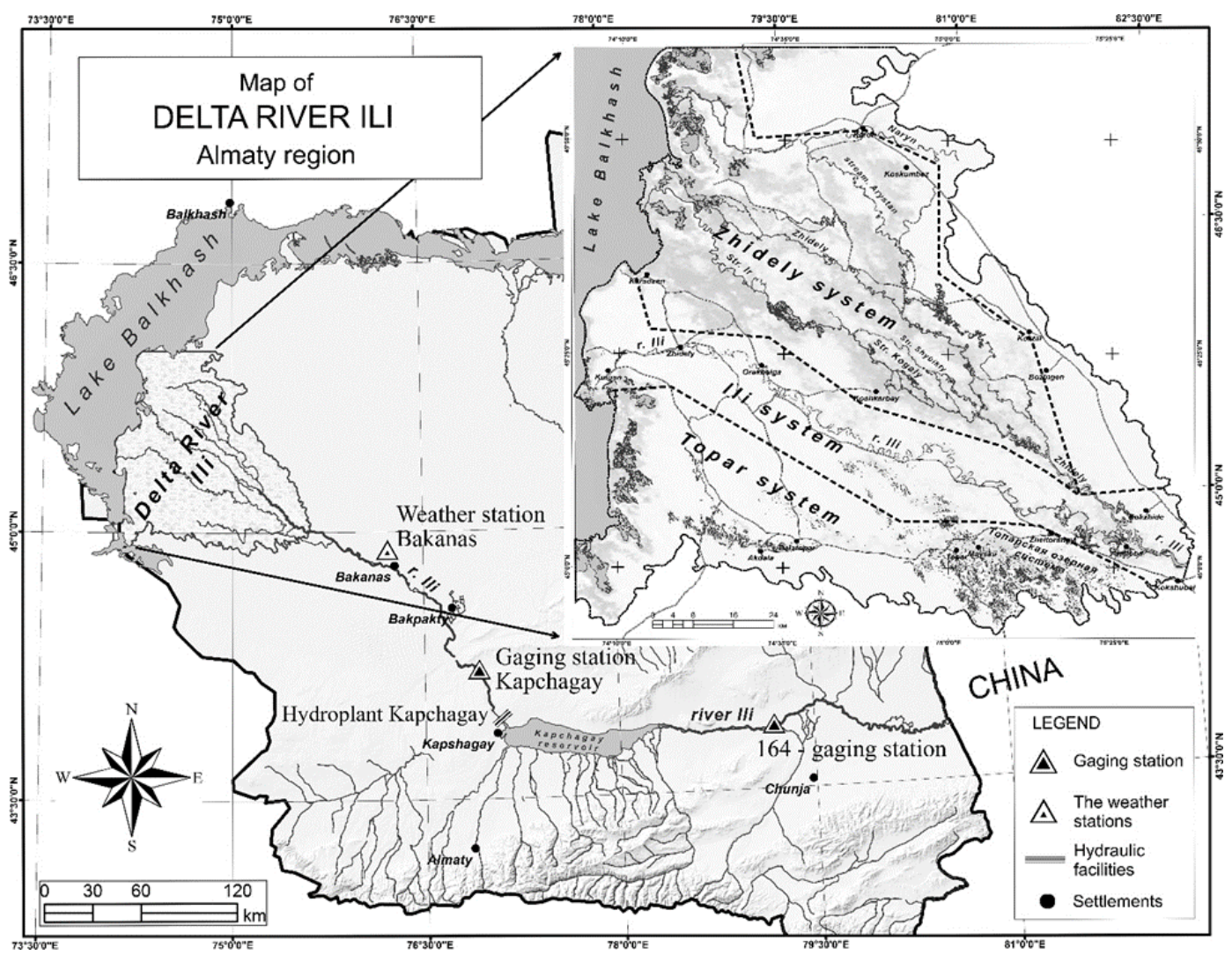

Figure 1. Map of the study region 


\section{Preprocessing satellite data}

To eliminate the radiometric, geometric and atmospheric distortions, all used satellite images have passed preliminary processing in accordance with conventional methods of Remote Sensing (Starodubtsev and Truskavetskij, 2007). The spatial resolution of images was unified to $30 \mathrm{~m}$. As single geographic coordinate system the Universal Transverse Mercator (UTM) was used.

\section{Classification}

Classification of hydromorphic and semi-hydromorphic ecosystems were carried out by using algorithm-supervised classification «Maximum Likelihood» as the most reliable and widely used algorithm for classifying the environment (Kanika et al., 2013; Hajdarov, 1963). For improving results and minimizing errors of classification ecosystems in 1979-1993 soil cover and geobotanical maps of 1981-1985 were used. For visual adjustment of boundaries of anthropogenic objects as ancillary data highresolution satellite images on Google Earth mode were used.

\section{Accuracy of the classification}

The accuracy of classification of ecosystems was estimated based on multinomial algorithm, known under the name "confusion matrix». Matrix differences is a static analysis, which uses cross-tabs to display the degree of difference between the classes obtained by supervised classification and a set of field data in reference points, which carry a more accurate information (Congalton and Green, 1999). Thus, the overall accuracy and accuracy of "producer" and "user" classification results of multi images from 1979 to 2014 (Table 2) have been calculated. Final accuracy of the derived class has been assessed by the Kappa coefficient, which is calculated by:

$$
\mathrm{\kappa}=\frac{N \sum_{i=1}^{n} x_{i i}-\sum_{i=1}^{r} x_{i+} x_{+i}}{N^{2}-\sum_{i=1}^{r} x_{i+} x_{+i}}
$$

where $x_{i i^{-}}$is the diagonal elements of the matrix's errors; $x_{i}+-$ is the total number of pixels in line; $x+i$-is the total number of pixels on the column; $N$ - is the total number of pixels in the matrix; $n$ - is the number of classes (Neasset, 1996).

Table 2. Classifications reliability of satellite images

\begin{tabular}{|c|c|c|c|c|c|c|c|c|c|c|}
\hline \multirow[b]{2}{*}{ Ecosystems } & \multicolumn{2}{|c|}{1979} & \multicolumn{2}{|c|}{1993} & \multicolumn{2}{|c|}{2000} & \multicolumn{2}{|c|}{2010} & \multicolumn{2}{|c|}{2015} \\
\hline & \begin{tabular}{|c|} 
Production \\
accuracy
\end{tabular} & $\begin{array}{c}\text { Custom } \\
\text { accuracy }\end{array}$ & $\begin{array}{c}\text { Production } \\
\text { accuracy }\end{array}$ & \begin{tabular}{|c|} 
Custom \\
accuracy
\end{tabular} & $\begin{array}{c}\text { Production } \\
\text { accuracy }\end{array}$ & $\begin{array}{c}\text { Custom } \\
\text { accuracy }\end{array}$ & \begin{tabular}{|c|} 
Production \\
accuracy
\end{tabular} & \begin{tabular}{|c|} 
Custom \\
accuracy
\end{tabular} & \begin{tabular}{|c|} 
Production \\
accuracy
\end{tabular} & $\begin{array}{c}\text { Custom } \\
\text { accuracy }\end{array}$ \\
\hline Grassland & 91.32 & 82.17 & 96.33 & 92.47 & 92.33 & 84.61 & 95.11 & 96.6 & 94.59 & 93.49 \\
\hline Reed & 91.85 & 98.4 & 93.76 & 98.78 & 91.85 & 99.18 & 97.32 & 97.07 & 93.76 & 96.46 \\
\hline Aquatic & 99.27 & 84.5 & 98.75 & 95.02 & 99.4 & 91.68 & 89.87 & 88.17 & 99.6 & 90.71 \\
\hline Total accuracy & \multicolumn{2}{|c|}{91.65} & \multicolumn{2}{|c|}{95.86} & \multicolumn{2}{|c|}{93.88} & \multicolumn{2}{|c|}{95.49} & \multicolumn{2}{|c|}{94.67} \\
\hline $\begin{array}{c}\text { The Kappa } \\
\text { coefficient }(\mathrm{K})\end{array}$ & \multicolumn{2}{|c|}{0.89} & \multicolumn{2}{|c|}{0.93} & \multicolumn{2}{|c|}{0.90} & \multicolumn{2}{|c|}{0.92} & \multicolumn{2}{|c|}{0.90} \\
\hline
\end{tabular}




\section{Results and discussion}

\section{The dynamics of hydrological regime and weather conditions in Ili River Delta 1950- 2013}

Since the 1970s there have been a trend in the reduction of average annual runoff of river Ili, primarily because of intensive building of irrigation systems and hydropower objects, both in China and in the Kazakh part of the Ili-Balkhash basin. It is known that due to the location of the main catchment area and hydrological regime, Ili River has a predominantly glacier-snow feeding. The riverhead of Ili is located at an altitude over $4000 \mathrm{~m}$ in the Tien-Shan mountain and numerous tributaries that considerably influence hydrological regime also have large catchment areas in mountains Zailiyskiy and Zhetysuskiy Alatau.

The annual runoff of Ili River before the building of Kapchagay hydropower plant was observed based on long-term data for the period of 1950-1969: spring flood in April-May, with an average monthly runoff of $455 \mathrm{~m}^{3} / \mathrm{s}$; three-month summer flood with an average monthly runoff $900 \mathrm{~m}^{3} / \mathrm{s}$ and seven-month autumn and winter low-water period with an average monthly runoff of $321 \mathrm{~m}^{3} / \mathrm{s}$. Maximum monthly average runoff was observed about $950 \mathrm{~m}^{3} / \mathrm{s}$ in July during the most intensive melting the of snowfields and glaciers (Fig. 2). Runoff begins to decline in September due to decrease in air temperature. Runoff begins to decline in September due to decrease in air temperature. Precipitation of the autumn period had no significant effect on volume runoff of Ili River and slump of runoff continued. Minimal value of runoff of the described period was around $200 \mathrm{~m}^{3} / \mathrm{s}$. and observed in winter months.

On average for the period of 1950-1969, the annual value of flow of Ili River from China to Kazakhstan was $12.47 \mathrm{~km}^{3}$ with an average runoff of $395.42 \mathrm{~m}^{3} / \mathrm{s}$ on the gauging station Dubyn. On the gauging station of Kapchagay it was increased until $14.9 \mathrm{~km}^{3}$ with an average runoff of $473 / 516 \mathrm{~m}^{3} / \mathrm{s}$ at expense of water inflow from Kazakhstan part of the Ili-Balkash basin. A significant reduction of Ili River runoff occurred from 1969, caused by the filling of Kapchagay reservoir since September 1969 and by increased water consumption due to irrigation in China and Kazakhstan. Before the building of hydropower plant the annual average runoff was $516 \mathrm{~m}^{3} / \mathrm{s}$, during the filling time (19701987) of Kapchagay reservoir it decreased by $28.2 \%$ to $370.2 \mathrm{~m}^{3} / \mathrm{s}$. At the same time, in the gauging station "164" the annual average runoff of Ili River was equal to $442 \mathrm{~m}^{3} / \mathrm{s}$. After the 1970s, the water runoff in the lower stream of river Ili never surpassed the runoff of the middle stream (Fig. 3).

The hydrological and atmospheric thermal conditions in the lower reaches of the river including the delta also changed dramatically with the beginning of the filling of Kapshagay reservoir. In seventeen years, there was a sharp more than $48 \%$ reduction of summer runoff and increased winter month runoff by $28 \%$ (Fig. 2). Winter floods have arisen that were not peculiar to Ili River, conditioned by increasing of water releases due to growth of energy needs during the cold season. Therefore, in winter the waves with a height up to $0.5 \mathrm{~m}$ from the Kapshagay power plant reached the upper reaches of the delta that caused ice drift, congestion and numerous spillages, which adversely affected biocenoses, especially the fauna. Despite the artificial discharges in May, spring floods did not achieve the scale of the former natural runoff of Ili River (Fig. 2).

In the following twenty-five years (1988-2013) in the same Kapshagay gauging station the annual average runoff of the Ili River has increased again to $466 \mathrm{~m}^{3} / \mathrm{s}$ however, without attaining the previous amount (Fig. 2). The dramatic reasons of increasing runoff 
to $47.6-60 \mathrm{~m}^{3} / \mathrm{s}$ are the result of regional warming. By results of investigation of glaciers from 1955 to 2004, the area of glacier systems of Kazakhstan part of Ili River Basin has decreased by $38.5 \%$, from 926.13 to $570.15 \mathrm{~km}^{2}$ (Vilesov et al., 2006). At the same time, due to the profound social and economic transformations in the 1990s and 2000s, the area of irrigated agriculture and water consumption have been reduced overall at the Kazakhstan part of the Ili-Balkhash basin (Burlibaev et al., 2011).

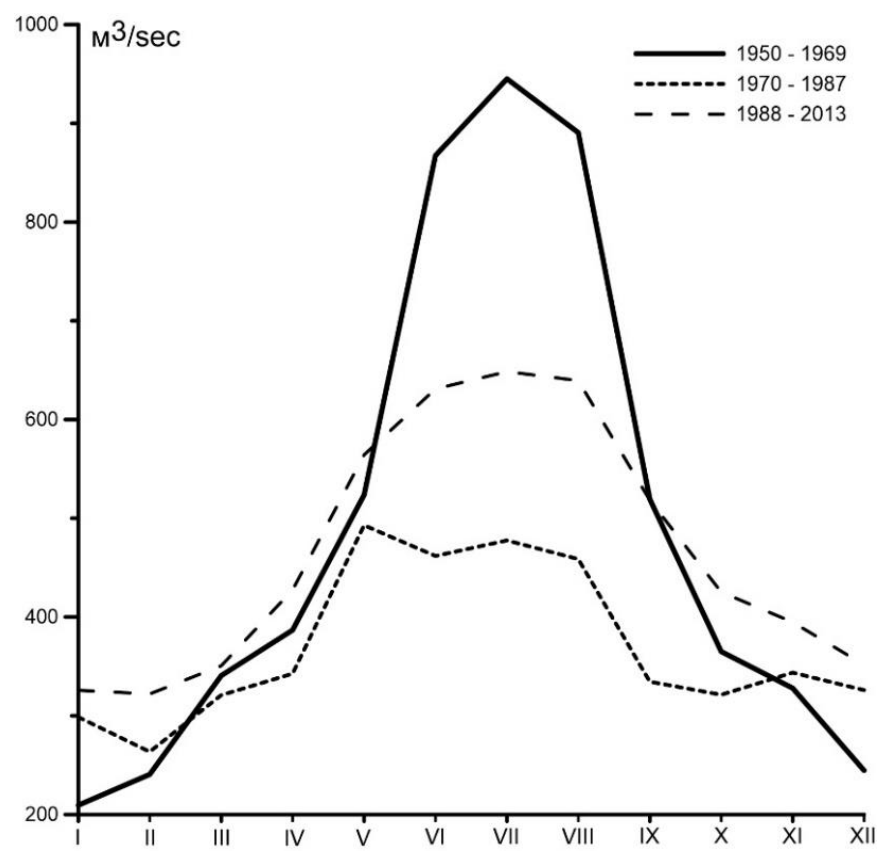

Figure 2. Monthly average runoff before building Kapchagay hydroplant 1950 -1969; during the filling time 1970-1987; after filling of Kapchagay reservoir 1988-2013; according to Kapchagai gauging station

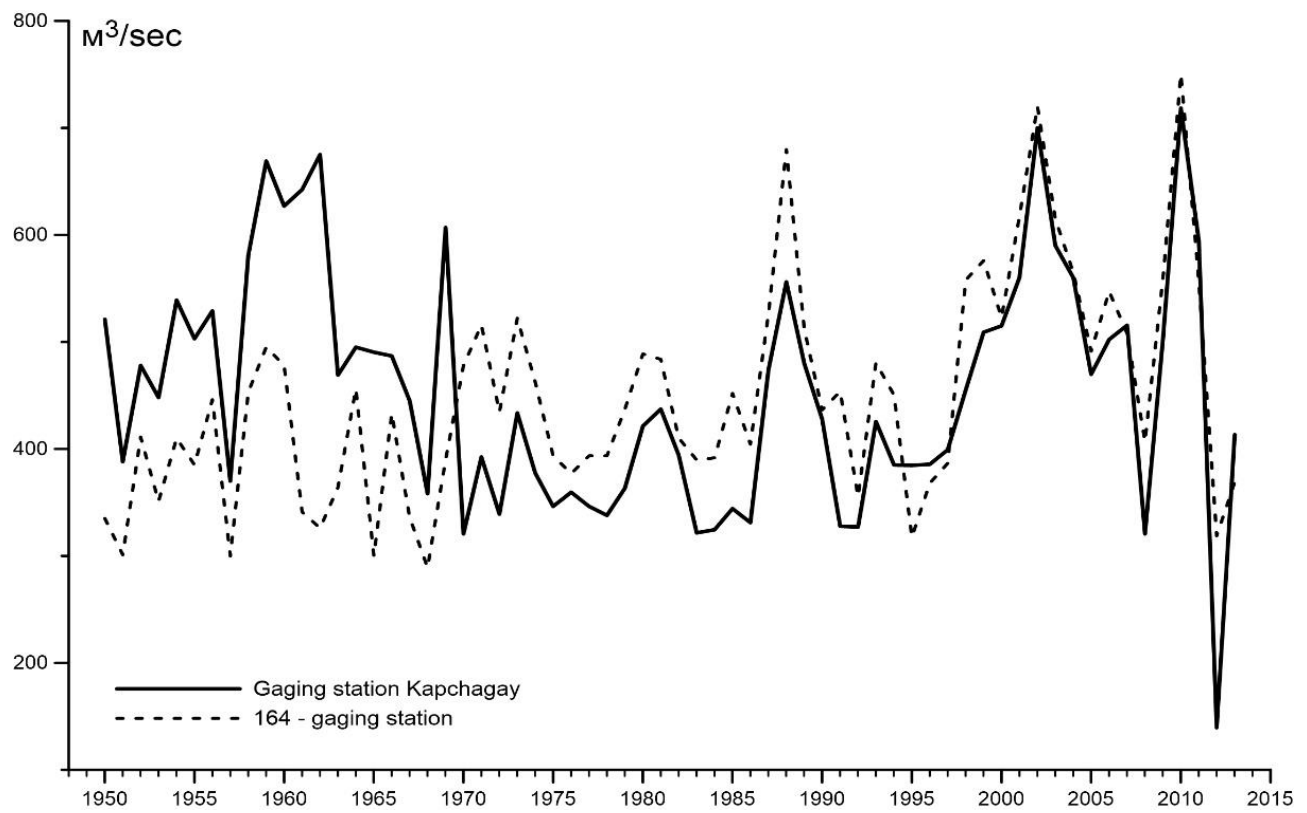

Figure 3. Combined schedule of annual runoff of average annual water content of Ile River in alignment of gauging station Kapshagai and gauging station 164 (1950-2013) 
An intensive construction of hydro-economic facilities in the Ili River Basin is accompanied by increasing water losses due to evaporation and filtration. After filling the Kapshagay reservoir $1.5-2.3 \mathrm{~km}^{3}$ of water was lost annually for evaporation and filtration. In lower and middle reaches of the Ili River with the Kapshagay reservoir a series of large irrigation massifs were activated causing large water losses in Shengeldy, Akdaly, Kerbulak and Karoi. Besides, unjustifiably high water consumption caused by the imperfection of irrigation systems with an efficiency coefficient of 0.59 (Burlibaev et al., 2004) and, in our opinion, cultivation of hydrophilous crops as rice and alfalfa was an unfortunate choice.

Thus, area of irrigated lands at 1986 in the Ili River Basin in Kazakhstan's part was 369.6 thousand ha, and by 2000 it was reduced until 299.2 thousand ha due to radical social and economic collision in Kazakhstan. In contrast, water consumption in the Chinese part of the basin increasing rapidly, where large hydraulic works had been built and continued to be built for intensively developing industrial and agricultural sectors, as well as a growing population of Xinjiang Uygur Autonomous Region (Burlibaev et al., 2004).

Analysis of satellite images shows the area of irrigated land on the Chinese side has reached 465500 ha already in 2007 and the annual water withdrawal from the Ili River in China has increased from 1.4 to $4.0 \mathrm{~km}^{3}$ (Starodubtsev and Truskavetskij, 2007). In the coming years active construction of water facilities in the Chinese part of the Ili River basin will continue, and this creates a serious problem of water scarcity, desertification of ecosystems in the South-East of Kazakhstan and, as a consequence, water sharing between China and Kazakhstan at government level.

The climate-geographical conditions and soil characteristics of much of the Kazakh part of the Ili River Basin refers to the northern deserts and semi-deserts and historically used as natural pastures for livestock and in particular for irrigated agriculture. Location of the delta in the center of Eurasia determines the continental climate with large daily temperature range and seasonal temperature. The highest average monthly air temperature is $25-27{ }^{\circ} \mathrm{C}$ observed in July, with an absolute maximum of $44-46^{\circ} \mathrm{C}$; the lowest average monthly temperature is $-13-15^{\circ} \mathrm{C}$ observed in January, with an absolute minimum of $-45^{\circ} \mathrm{C}$.

The amount of positive annual temperatures above $10{ }^{\circ} \mathrm{C}$ reaches to $3500{ }^{\circ} \mathrm{C}$ that is the cause of high evaporation around $1000 \mathrm{~mm} /$ year in the delta area and Balkhash Lake and extra-arid climate. The average annual precipitation in the delta during 1970-2012 was little less than $160 \mathrm{~mm} /$ year, with a range of $80-260 \mathrm{~mm} /$ year that is about $13 \%$ of total evaporation. According to our data in the summer, the humidity can vary between 25 and 30\% in the course of day and content of moisture in the soils at depth of 12-24 $\mathrm{cm}$ can vary between 1-2\%. Hence, hydrological regime of the Ili River has a determinative importance on the state of intrazonal hydromorphic biocenosis of delta and the conservation of Balkhash Lake.

\section{The negative anthropogenic impacts on the delta biocenoses}

The lower reaches of the Ili River from the Kapshagai gorge to estuary occupies the western part of the Balkhash flat depression with an area of more than $20000 \mathrm{~km}^{2}$ (Hajdarov, 1968). Geomorphologically situated in the lower reaches the modern Ili Delta it covers an area about 7,000 $\mathrm{km}^{2}$. On the top of the modern delta, about $120 \mathrm{~km}$ from the shore of Balkhash Lake, Ili River divides into many deltaic channels, which form three major hydrographic systems: Toparsky, Ilisky and Zhidelinsky (Fig. 1). Each 
of them, in its turn divides into smaller channels. Large part of the delta occupies the vast depressions between channels bounded by hilly sands that are flooding forming a shallow lakes and marshes.

Flat relief of the Balkhash depression and granulometric soil structure: light clay loams, loamy sands, fine-grained sands, as well as significant fluctuations of water content of the Ili River caused the variability of hydrographic system: some of the streams and channels are silting and disappear, others are increasing and new ones appear.

The system of lakes and swamps of deltaic territories are also very dynamic. The study area of the Ili Delta varies with the largest species and cenotic diversity in the region, with the presence of fertile land, rich natural pastures and hayfields, with an extensive hydrographic network of lakes, canals and sleeves with commercial fish fauna and bird colonies. It has been under intense economic use from the beginning of the formation of the modern delta over the years. This has led to a violation of the integrity of plant communities and caused great damage to the rich fauna of the region. With regard to vegetation this is reflected in a simplified structure of the communities, in impoverishment of their species composition, in reducing or complete disappearance of the most valuable indigenous species, in increasing the number and biomass of secondary species (including fault indicators, etc.), in reducing the role of perennial species and in increasing the specific value of annual plants. Negative processes are caused by unsystematic livestock grazing, uncontrolled burning of low productivity grass and last year's reed beds, as well as by cutting riparian and saxaul forest during harvesting for the winter. The number of livestock in the delta area reached 101.7 thousand units, sheep and goats account for $-50.8 \%$, cattle $-38.4 \%$, and horses $-10.8 \%$. Negative delta transformation of biocenosis are particularly strongly expressed in the vicinity of settlements, livestock sheds on distant pastures and close to water bodies. Restoration of vegetation in desert is going slowly, due to the harsh climate, soil poverty, poor water content and high salinity of groundwater. Therefore, floristic diversity is reduced now almost on the entire territory, and for its restoration requires different phytomeliorative events. Vertebrate fauna of the region has about 345 species, that includes 33 rare and endangered animals, which are also under threat from poaching, habitat degradation, disturbance growth at the moment. The load on the ecosystem of the delta from huge number of tourists, hunters and fishermen on private cars, motorcycles and water transport is practically not regulated, especially those that are heavily influencing on floodplain, riparian and wetland biocenoses and vertebrate fauna as well.

Pollution of surface water and terrestrial ecosystems by various pollutants, household, industrial, agricultural effluents and emissions are increasing. Violation of hydrological and hydrochemical regime of the Ili River has a particularly devastating impact on the floodplain and deltaic wetland ecosystems.

\section{Regional climate change in the study region from 1970-2013}

Precipitation regime in the study area has been considered with 2 meteorological stations for the period of 1971-2013. In the annual course precipitation maximum occurs in spring months (April-May) and secondary maximum was observed in the fall. The minimum amount of precipitation falls in August and September, as well as in January and February across the study area. In general, rainfall throughout the year dominates in the warm period. Taking into account high evaporation in the delta region, long-term fluctuations in average precipitation sums cannot play a decisive role. An analysis of the 
linear trend in temporary course of annual precipitation sums and precipitation sums for warm and cold periods on both considered meteorological stations have shown weak trends. The maximum positive value $1.5 \mathrm{~mm} / 10$ years of the linear trend coefficient had been observed at Bakanas meteorological station. The character of changes in precipitation during the warm period of the year roughly corresponds to the annual. A negative trend (minus $1.2 \mathrm{~mm} / 10$ years) was noted in Bakanas. In the cold season there is a weak positive trend (3-6 mm/10 years) or sometimes it is not possible to observe them at all.

At the same time, the main volume of the Ili River flow is formed by precipitations in the catchment part of the basin, which is situated in the mountains at an altitude of over 2,000 $\mathrm{m}$, where the average annual rainfall is equal to $900-1100 \mathrm{~mm}$. For example, 2010 was an abnormally high-water year for the Ili River, according to Shymbulak (2300 m. above sea level) and Myn Zhylki (3100 m above sea level) meteorological stations, which are located in the valley Maloalmatinskoe in Zailiysky Alatau, that fell on 50\% of precipitation more than the average annual rainfall for the period 2000-2009.

An analysis of the linear trend in temporary course of annual precipitation shows that despite the great variability of precipitation from year to year in considered period (1971-2013) trends are expressed weakly, but in general, the average annual amount of precipitation decreased to $10 \mathrm{~mm}$ according to Bakanas and Kuigan weather stations for 44 years (Fig. 4).

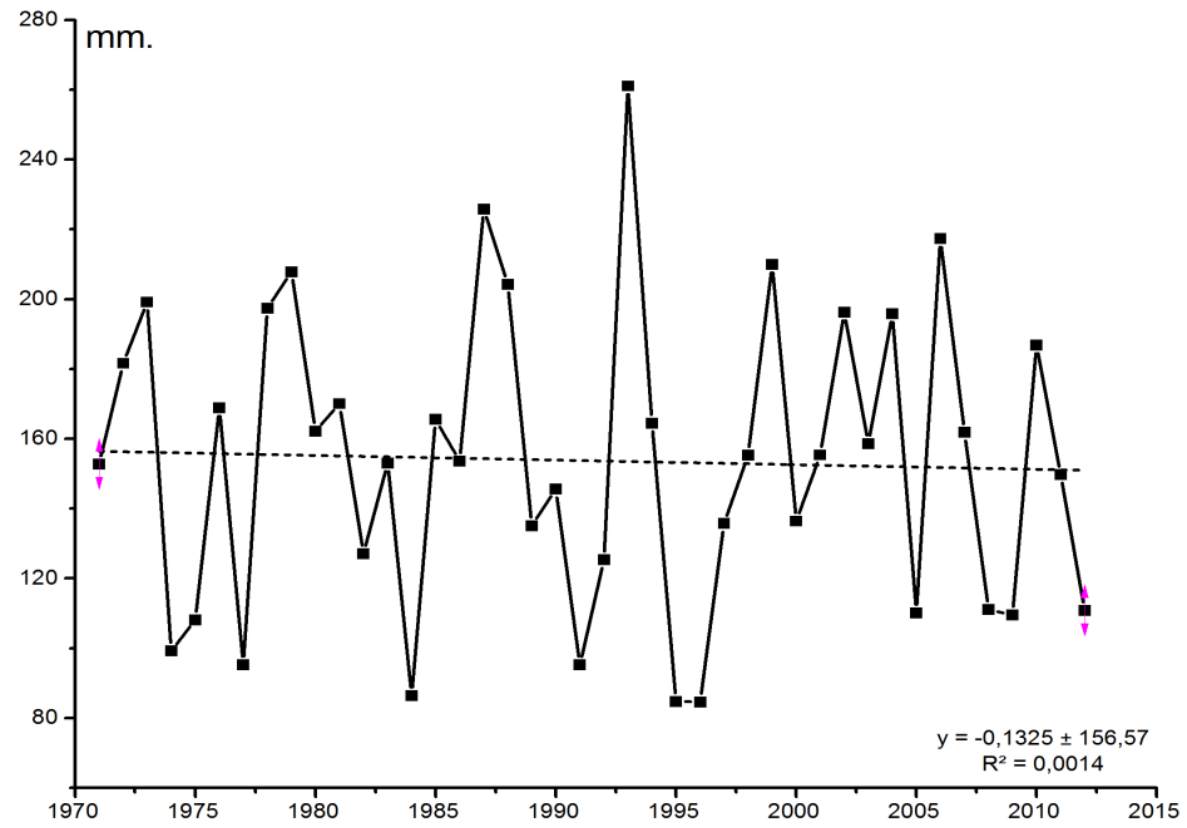

Figure 4. Average annual amount of precipitation in Bakanas and Kuigan meteorological stations

The main characteristics of temperature regime are average annual and average monthly air temperature, as well as absolute maximum and absolute minimum. Deviations of the actual temperature from its long-term average (norm) give an idea about temperature variation. Long-term data (1970-2013) on the air temperature provided by Bakanas and Kuigan weather stations (Fig. 5) were the source material for the study. 
The annual course that is ordinary for a continental climate, when the warmest month is July and the coldest - January, is typical for the whole territory. The average monthly air temperature can vary significantly from year to year. Therefore, in addition to the monthly values in the description of the climatic conditions it is important to have data on their variability. The highest interannual variability is possessed by the winter months, and the smallest by the summer months. So the long-term average air temperature in January may vary from $-7.3{ }^{\circ} \mathrm{C}$ to $-14.6{ }^{\circ} \mathrm{C}$, and in July from $23.8{ }^{\circ} \mathrm{C}$ to $26.0{ }^{\circ} \mathrm{C}$. Variability of air temperature fluctuates during the winter months from $3.7^{\circ} \mathrm{C}$ to $5.1{ }^{\circ} \mathrm{C}$, and in the summer months from $1.0^{\circ} \mathrm{C}$ to $1.5^{\circ} \mathrm{C}$.

Temperatures of warm period of the year, especially in the summer are fairly stable, and its interannual variability is minimal in comparison with other months of the year. The absolute maximum of temperature was recorded in Kuigan meteorological station $\left(46^{\circ} \mathrm{C}\right)$ in 1983 , and at Bakanas meteorological station $\left(45^{\circ} \mathrm{C}\right)$ in 1997 . The absolute minimum of air temperature was observed in 1969 and amounted minus $43{ }^{\circ} \mathrm{C}$ in Bakanas and (minus $41{ }^{\circ} \mathrm{C}$ ) in Kuygan. The daily amplitude, that is the difference between the daily maximum and minimum of temperature gives an idea of the weather variability. Its highest values are confined to the warm period (April-September) and constitute 13.1$19.3{ }^{\circ} \mathrm{C}$ (Bakanas), and the lowest - in winter (December-February) - are 8.2-12.2 ${ }^{\circ} \mathrm{C}$ (Bakanas). The daily amplitude in clear weather is much greater than in cloudy. In the high water year 2010 the average monthly air temperature for January-September was near normal in the study area, almost all the months were warm, with the exception of February and July. January was very warm and the average monthly air temperature at all stations was above the long term average $3.8-4.3{ }^{\circ} \mathrm{C}$. February was abnormally cold with temperatures below the long term average $1.6-4.3{ }^{\circ} \mathrm{C}$ and in July air temperature was 23.7-24.4 ${ }^{\circ} \mathrm{C}$, so that was lower by $1.1-1.3{ }^{\circ} \mathrm{C}$ than the average of long term average values. The air temperature in other months fluctuated within normal limits. An analysis of factual material on the air temperature and precipitation for 2010 and 2011 have shown that the positive trend in the annual air temperature and in annual precipitation sum, that identified material for many years (1971-2008) is preserved (Fig. 5).

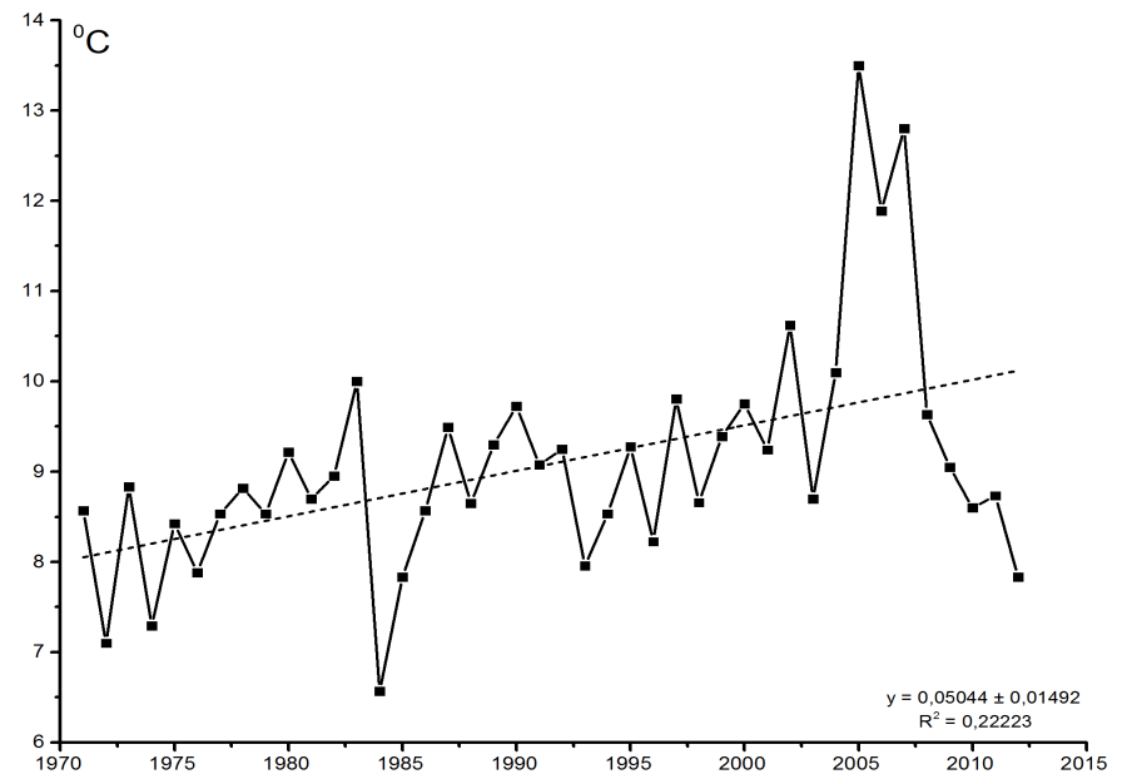

Figure 5. The graph of long-term dynamics of average annual temperature at Bakanas meteorological station 


\section{Monitoring of Ili Delta for 1979-2015 on satellite images}

Reducing the average annual runoff in lower reaches of the Ili River from $472 \mathrm{~m}^{3} / \mathrm{s}$ (1948-1969) to $361 \mathrm{~m}^{3} / \mathrm{s}$ (1970-1986) and the lowering of water level by $1-1.5 \mathrm{~m}$, as well as changes in the natural hydrological regime of water releases by Kapshagai hydropower plant significantly worsened the flooding of the delta region of the river. Additionally, it was the reason for the drying of many flowing and stagnant lakes, reducing the area of reed massifs, salinization of soils and desertification of shores. Thus, these negative processes extend from the least watered peripheral part of the delta, which is adjacent to the coast of the Balkhash, to its top.

To identify the features of the dynamics of intra-zonal ecosystems depending on the water content of the river in different years, areas of hydromorphic ecosystems (meadows, reed, aquatic) were defined in dry years $(1979,1993,2015)$, in a year with average water flow (2000) and in a year abnormally abounding in water (2010). As the analysis of satellite images show, significant amplitude of fluctuations of the delta watering have caused corresponding dynamic changes in the area of hydromorphic ecosystems, the total area and the relation between them have varied in a wide range (Table 3). Specially marked dynamics in changing the wetland area attracts attention. So according to Hydroproject the total delta area of the Ili River was $7740 \mathrm{~km}^{2}$ in 1948 , and $841 \mathrm{~km}^{2}$ of them accounted for an open water surface of delta lakes and ducts (Hajdarov, 1963). And 50 years later, in 2000 lakes and ducts area on the basis of our data, has decreased by $36 \%$ and amounted to $540 \mathrm{~km}^{2}$. However, after 2010 the abnormally high-water year the open water of lakes and ducts enormously increased, reaching $1177.7 \mathrm{~km}^{2}$.

Table 3. Areal ratio of hydromorphic Ili Delta ecosystems $\left(\mathrm{km}^{2}\right)$

\begin{tabular}{c|c|c|c|c|c|c|c|c|c|c}
\hline \multirow{2}{*}{ Date of space images } & \multicolumn{2}{|c|}{$\mathbf{1 9 7 9}$} & \multicolumn{2}{c|}{$\mathbf{1 9 9 3}$} & \multicolumn{2}{c|}{$\mathbf{2 0 0 0}$} & \multicolumn{2}{c|}{$\mathbf{2 0 1 0}$} & \multicolumn{2}{c}{$\mathbf{2 0 1 5}$} \\
\cline { 2 - 9 } & $\mathbf{1 9 7 8}$ & $\mathbf{1 9 7 9}$ & $\mathbf{1 9 9 8}$ & $\mathbf{1 9 9 3}$ & $\mathbf{1 9 9 9}$ & $\mathbf{2 0 0 0}$ & $\mathbf{2 0 0 9}$ & $\mathbf{2 0 1 0}$ & $\mathbf{2 0 1 4}$ & $\mathbf{2 0 1 5}$ \\
\hline $\begin{array}{c}\text { The average annual water content } \\
\text { on of Ili River at "Tract } \\
\text { Kapchagai" gauging station }\end{array}$ & 337.9 & 363.2 & 327.1 & 425.5 & 509.0 & 515.0 & 503.0 & 718.5 & 220.0 & $\begin{array}{c}\text { No available } \\
\text { data }\end{array}$ \\
\hline Aquatic ecosystems & \multicolumn{2}{|c|}{438.0} & \multicolumn{2}{|c|}{393.7} & \multicolumn{2}{|c|}{540.4} & 1177.7 & 539.9 \\
\hline Grassland ecosystems & 1767.6 & 1148.7 & 1153.1 & 1340.6 & 1895.6 \\
\hline Reed ecosystems & 1771.0 & 1669.2 & 2630.9 & 3027.3 & 2430.0 \\
\hline $\begin{array}{c}\text { The total area of hydromorphic } \\
\text { ecosystems }\end{array}$ & 3538.6 & 2817.9 & 3784 & 4367.9 & & 4325.6 \\
\hline
\end{tabular}

The study of the temporal dynamics of the transformation of the delta ecosystems by satellite images revealed the following changes (Fig. 6):

1979

Analysis of satellite imagery that was made during the filling of Kapchagai reservoir showed pronounced negative changes of hydromorphic and semi-hydromorphic ecosystems. Low water period in lower reaches of the Ili River continued from 1970 to 1986. This caused desiccation of the major large delta lakes of the Zhideli system: Blue, White and Kaldayakskoe with a total area of $11 ; 3.5$ and $45 \mathrm{~km}^{2}$, respectively. Most ducts of the Zhideli system has been lost. Zhideli duct and its secondary ducts on the right side, such as Shybykty, Kertyubel, Zhalasar, Ketpenkaldy and partially Arystan 
ducts that feed the eastern part of the delta and their surrounding hydromorphic ecosystems strongly have become shallow. Unique Topar lake system has undergone a massive transformation and drying, where the water content of major ducts such as Topar I (Suminka) and Topar II did not exceed $1.4 \%$ of the Ili River flow. This is explained by a weak elaboration of Topar riverbed and its great fragmentedness due passive follow to local relief. The total water surface area of the Topar system was 120 $\mathrm{km}^{2}$ in 1979, that is $220 \mathrm{~km}^{2}$ less than in 1948. There has also been drying up of lakes and Topar side ducts such as Balatopar, Kishpa, Aksyir, Koktal that filled inter-ridge depressions before.

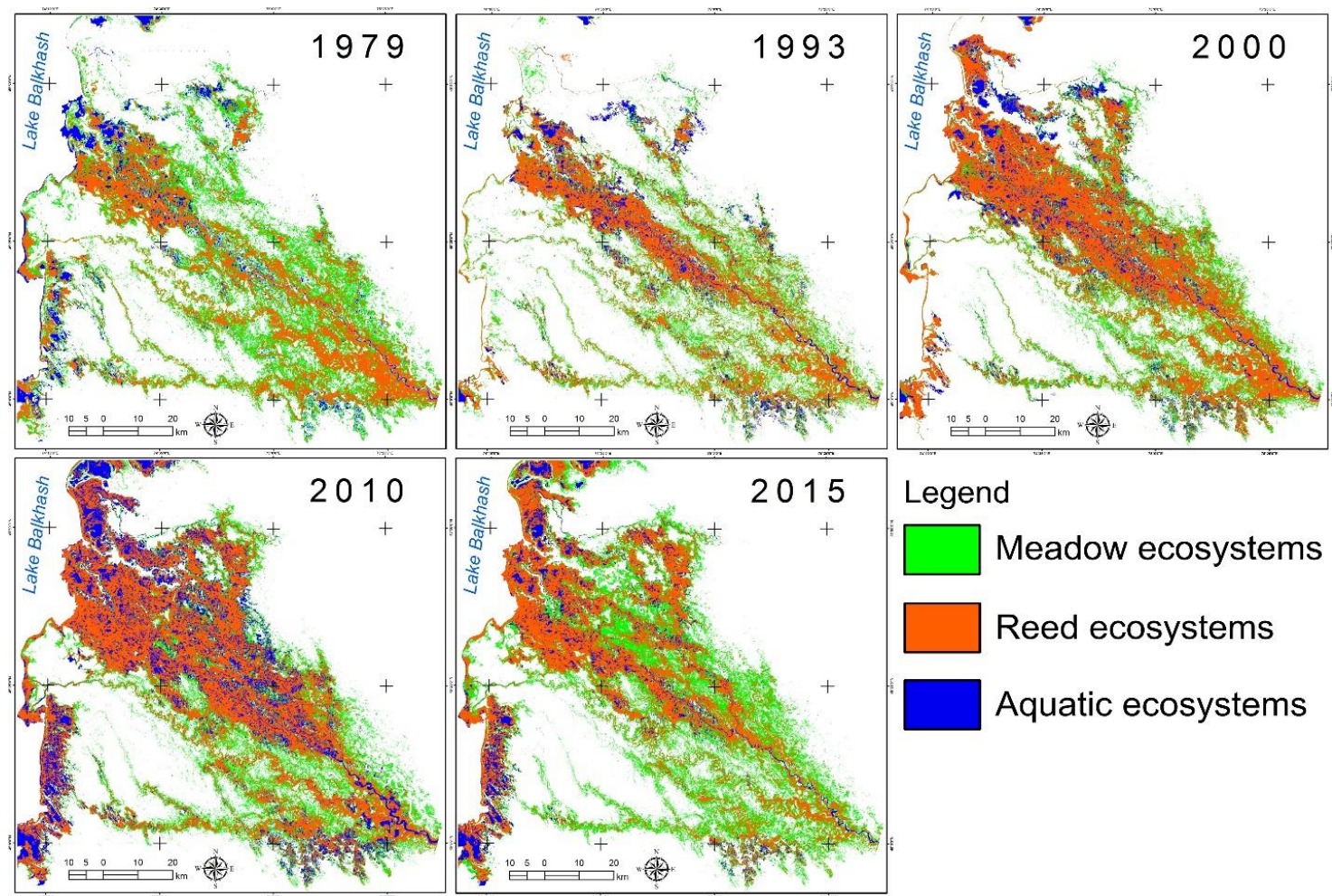

Figure 6. Dynamics of area change of major ecosystems in the Ili Delta in 1979-2015

1993

Despite the sharp decrease the area of irrigated land in the Kazakh part of the Ili basin in the 1990s there was a three-year water shortage during 1990-1992. The average water flow rate was $327.4 \mathrm{~m}^{3} / \mathrm{s}$ and this led to sharp deterioration of general status and reducing the area of hydromorphic and semi-hydromorphic ecosystems for $720 \mathrm{~km}^{2}$ in comparison with 1979. Such a sharp drop in runoff in lower reaches of the Ili River is explained by artificial changes in the hydrological regime by the Kapshagai hydropower plant. As a result, the level of the reservoir has increased by $23.5 \mathrm{~cm}$ during the period of 1990-1993, and the water surface area has increased from $1150 \mathrm{~km}^{2}$ to $1244 \mathrm{~km}^{2}$.

The sharp decline in the average annual runoff in lower reaches of the Ili River from $503 \mathrm{~m}^{3} / \mathrm{s}$ to $327.4 \mathrm{~m}^{3} / \mathrm{s}$ and the reduction of the level of Balkhash Lake by $25 \mathrm{~cm}$ from the nominal level $341.30 \mathrm{~m}$ occurred. This has led to the drying up of the aquatic, particularly coastal ecosystems and to the subsequent large-scale desertification of the Ili Delta's hydromorphic and semihydromorphic ecosystems, which is clearly observed 
in the picture in 1993. It should be highlighted that the total disappearance of lake systems - former bays of Balkhash Lake, were previously a part of the Topar system. The largest of them are Semizkol, Akkol, Bogatoe and Abishkol with the total area of $39.4 \mathrm{~km}^{2}$, which had links with Aksiyr ducts from the Topar system in the 40-ies of the last century. Reducing the level of Balkhash Lake as in 1979 has led to the drying up of the major lakes of Zhideli System such as - Sinee, Beloe, Kaldayakskoe and Nauryzbaevskoe. Moreover, it has led to extended arm of large bays Majtán and Balakashkan, which penetrated into the delta for 10-15 km. Desertification of hydromorphic and semi-hydromorphic biocenoses took place on the periphery of the Zhideli system, especially in the eastern part. In the full-flowing years the lake, such as Erimbay dominated by flowing, where the runoff is carried out during the whole year.

2000

The annual average runoff of Ili River increased from $360 \mathrm{~m}^{3} / \mathrm{s}$ up to $430 \mathrm{~m}^{3} / \mathrm{s}$ in the period from 1993 to 2000 . This has led to the expansion of the area of hydromorphic ecosystems, including reed community and meadow-bog cenoses in the northern periphery of the Zhideli system. Thus, the runoff increase on $19.5 \%$ has increased the area of hydromorphic and semi-hydromorphic ecosystem to $966 \mathrm{~km}^{2}$. The proportion of aquatic ecosystem is also increased to $146.7 \mathrm{~km}^{2}$ due to flooding and restoration of large deltaic lakes - Sinee, Beloe and Nauryzbaevskoe, which had dried during the period of 1979-1993.

At the same time, further drying processes and increase in the areas of desertification occurred in the Topar system. Increasing the level of Balkhash Lake to the mark of $341.54 \mathrm{~m}$ above sea level is not particularly wag on coastal lake systems (Semizkol, Akkol, Bogatoe and Abishkol), which are mainly recharged by groundwater inflow from the Balkhash.

2010

The average runoff of the Ili further increased and reached $538.6 \mathrm{~m}^{3}$ in the period of 2001-2010. The record for 2010 and the last 60 years of water content observing notices difference, because the water content reached $718.5 \mathrm{~m}^{3} / \mathrm{s}$. This led to a significant increase in the area of all hydromorphic ecosystems, especially in the central and peripheral parts of the Zhidelinsk system and in a lesser degree, the first time after the $60 \mathrm{~s}$, in the Ili duct system where flooding phenomenon was detected. Appreciable growth of hydromorphic biocenosis was also observed at the head of the most abounding Topar system, where the total water surface area was $284 \mathrm{~km}^{2}$, where the total water surface area was $284 \mathrm{~km}^{2}$ not reaching the index in 1948, it achieved only $63 \mathrm{~km}^{2}$.

In 2010, in the Ili River basin three waves of flood occurred - winter $411 \mathrm{~m}^{3} / \mathrm{s}$ (from October to February), spring $739 \mathrm{~m}^{3} / \mathrm{s}$ (from March to May), summer $1155 \mathrm{~m}^{3} / \mathrm{s}$ (from June to September), which is typical for a river with glacial feeding. Due to the significant increase in the water content of the River Ili and its tributaries, in many areas of the lower reaches, in the delta, spills and floods formed, which significantly changed the water regime and environmental conditions in aquatic and semi-aquatic ecosystems of the territory. 
Since the 12th May 2014 the Ili River runoff on the Kazakh-Chinese border sharply fell, from $291 \mathrm{~m}^{3} / \mathrm{s}$ to $90 \mathrm{~m}^{3} / \mathrm{s}$. The level of water in the Kapchagai reservoir decreased by $113 \mathrm{~cm}$. Throughout the more than a century of instrumental hydrological observations of such flow reduction.

This caused a sharp reduction in the area of reed communities of the Zhideli system, firstly in the place of head part. In the middle and in the peripheral part the reed plant communities were preserved. In the Topar system drying of meadow and marsh phytocenoses was observed. Drying processes spread from the head of the Delta to the periphery, to the north direction. Based on an analysis of satellite images, it can be concluded desertification processes in most parts of the delta, particularly in the central regions of the Zhidelinsk system was expressed. Compared with 2010 semihydromorphic ecosystem area decreased by $555 \mathrm{~km}^{2}$ and reed area by $597 \mathrm{~km}^{2}$, which shows the extent of ongoing desertification processes. Reduction of aquatic ecosystems is observed at the head of the delta, where significant drying of large lakes occurred (Table 4).

Table 4. Change of area ratio in Zhideli system delta lakes

\begin{tabular}{c|c|c|c|c|c|c}
\hline \multirow{2}{*}{ Year } & \multicolumn{7}{|c}{ Lake name } \\
\cline { 2 - 7 } & Siniy & Belyiy & Kaldayakskie & Nauryizbaevskoe & Asaubay & Kokol \\
\hline 2010 & 10.84 & 2.52 & 38.51 & 8.68 & 9.22 & 17.87 \\
2015 & 9.32 & 2.18 & 17.08 & 3.58 & 5.27 & 8.19 \\
\hline
\end{tabular}

\section{Conclusion}

In summary, it is supposed that the main anthropogenic factors that have a significant, often negative, impact on intrazonal half and hydromorphic ecosystems downstream of the Ili River include:

1. Regulation of water flow and decrease in water availability considering Ili River and its tributaries in China and Kazakhstan, in spite of the total increase in river flow due to degradation of glaciers in mountainous areas of the catchment basin of Ili.

2. Economic activities of the local population, as well as leisure travelers, hikers, hunters, fishermen, etc., adversely affecting the landscape, flora, plant communities, fauna and habitats of animals.

3. There is an urgent need to develop and implement a program of rational use of water resources of Ili-Balkash basin, including the modernization of irrigation systems, as well as the introduction of drought-resistant agricultural crops, water-saving technologies in the industrial and utilities sector.

4. Pollution of surface and ground water and terrestrial ecosystems with various pollutants, household, industrial and agricultural effluent sand emissions.

5. Related to the global and regional climate changes that lead to a marked increase in the average annual air temperature and reduction the number of drop-down in the region of precipitation, increase desertification process.

All of these factors which are strong and continuously increasing under human impacts since the early 70 s and make less noticeable climatic changes, put unique 
ecosystems of the lower reaches of the Ili River, including its delta and Lake Balkhash, in a position that is more and more difficult to resolve causing to face the ecological crisis very reminiscent of the Aral Sea catastrophe. Naturally, the importance of each of these factors varies for different types of ecosystems. Anthropogenic factors are less effecting to the desert biocenosis remote from populated areas and water bodies. Because of the extra arid climate, they are not used for commercial purposes and are not visited by tourists. Their condition is determined mainly by climatic geographical features of the territory, whereas state hydromorphic delta ecosystems depends mainly on the factors of human nature.

At the same time, the state of soil and vegetation, especially wetlands, mainly determined by the water content of the Ili, and the condition of the animal world, especially commercial species of vertebrate fauna, by environmental services. Considering the continuously growing water demand, both in the Kazakh and especially in the Chinese part of the Ili basin, one should expect a significant further reduction of the hydromorphic ecosystems deltaic areas. The hydrographic Zhideli-Kogalinsk network system has the best prospects for the partial preservation of the unique intrazonal ecosystems.

Solving the problem of maintaining the water content in the lower reaches of the Ili River at an acceptable level is impossible without intergovernmental agreement between China and the RK on water allocation and a cardinal restructuring of irrigation and water distribution systems.

\section{REFERENCES}

[1] Burlibaev, M. Z., Volchek, A. A., Kalinin, M. J. (2004): Gidrometricheskie imerenija i gidrogeologicheskie raschety dlja vodohoz jajstvennyh tselej. - Kaganat, Almaty.

[2] Burlibaev, M. Z., Dostaj, Z. D., Mirhashimov, I., Nikolaenko, A. J. (2011): Sovremennoe sostojanie hozjajstvennoj dejatel'nosti $\mathrm{v}$ Ile-Balhashskom bassejne. Integrirovannoe upravlenie vodnymi resursami v Ile-Balkashskom bassejne. - UNDP, Almaty, pp. 3-16.

[3] Cherednichenko, A. V. (2010): Izmenenie klimata Kazahstana i vozmozhnosti adaptatsii za schet dostupnyh vodozapasov oblachnosti. - Ilim, Bishkek.

[4] Congalton, R. G., Green, K. (1999): Assessing the Accuracy of Remotely Sensed Data: Principles and Practices. - Lewis, Boca Raton, FL.

[5] Du, Z., Linghu, B., Ling, F., Li, W., Tian, W., Wang, H. (2014): Analysis of Landsat-8 OLI imagery for land surface water mapping. - Remote Sensing Letters 5(7): 672-681.

[6] Evstifeev, J. G., Egrohin, O. G., Nasyrov, R. M. (ND): Pochvennaja karta Semirech'ja. M:500 000 TOO. - Kazakh Scientific research institute of soil study and crops named after U Uspanov.

[7] Frazier, P., Page, K., Louis, J., Briggs, S., Robertson, A. I. (2003): Relating wetland inundation to river flow using Landsat TM data. - International Journal of Remote Sensing 24: 3755-3770.

[8] Hajdarov, R. M. (1963): Gidrologicheskij ocherk. V kng. - In: Lomonovicha, M. I. (ed.) Ilijskaja dolina, ee priroda i resursy / AN Kaz. SSR. Pod obsch. Izd-vo Akad. nauk KazSSR, Alma-Ata, pp. 238-249.

[9] Hajdarov, R. M. (1968): Dinamika del'ty r. Ili. - Trudy GGI, Vyp. 160: 180-221.

[10] Jensen, J. R., Ramsay, E. W., Mackey, H. E., Christensen, E. J., Sharitz, R. P. (1987): Inland wetland change detection using aircraft MSS data. - Photogrammetric Engineering and Remote Sensing 53: 521-529. 
[11] Kanika, K., Anil, K. G., Rhythm, G. (2013): A comparative study of supervised image classification algorithms for satellite images. - International Journal of Electrical, Electronics and Data Communication 1(10): 10-16.

[12] Magasheva, R. (1977): Meliorativnye uslovija sovremennoj del'ty reki Ili i ih izmenenija v svjazi s zaregulirovaniem stoka Kapchagajskim vodohranilischem. - Avtoref. kand. dis., Alma-Ata.

[13] Neasset, E. (1996): Use of the weighted Kappa coefficient in classification error assessment of thematic maps. - International Journal of Geographical Information Systems 10(5): 591-603.

[14] Plisak, R. P. (1981): Izmenenie rastitel'nosti del'ty reki Ili pri zaregulirovanii stoka. Nauka, Alma-Ata.

[15] Plisak, R. P., Ogar, N. P. (1985): Karta rastitel'nosti sovremennoj del'ty r. Ili. M 1:300 000. M. edition.

[16] Sovolova, N. P., Zhelnova, N. I. (1984): Karta kormovyh ugodij Balhaschskogo rajona Alma-Atinskoj rajona Alma-Atinskoj oblasti KazSSR. M. 1:300 000. Karta sostavlena po materialam polevogo obsledovanija v 1981 g. - MSH SSR Institute, Kazgiprozem.

[17] Starodubtsev, V. M., Truskavetskij, S. R. (2007): Degradatsija pochv del'tah rek.Problemy osvoenija pustyn 2: 26-29.

[18] Starodubtsev, V. M., Nekrasova, T. F., Popov, J. M. (1978): Aridizatsija pochv del'tovyh ravnin Juzhnogo Kazahstana v svjazi s zaregulirovaniem rechnogo stoka. - Vodnye resursy 5: 14-23.

[19] Tso, B., Mather, P, M. (2009): Classification Methods for Remotely Sensed Data. 2nd Ed. Chaps. 2-3. - Taylor and Francis Group, USA.

[20] Vilesov, E. N., Gorbunov, A. P., Morozova, V. N., Severskij, E. V. (2006): Degradatsija ledenenija i kriogenez na sovremennyh morenah severnogo Tjan'-Shanja. - Kriosfera Zemli 1: 69-73. 